\title{
WHISTLE-BLOWING POLICY: AN IMPERATIVE FOR QUALITATIVE EDUCATION IN NIGERIA
}

\author{
Ivy I. Nebe ${ }^{1 \star}$, Fadeke E. Owolabi ${ }^{2}$ \\ ${ }^{1}$ Ms.c Candidate, Department of Political Science \& International Relations, \\ Covenant University, Ota-Nigeria, ivy.nebepgs@stu.cu.edu.ng \\ ${ }^{2}$ Phd, Department of Political Science \& International Relations, Covenant \\ University; fadeke.owolabi@covenantuniversity.edu.ng \\ ${ }^{*}$ Corresponding Author
}

\begin{abstract}
Corruption is a high-headed monster that has eaten deep into all spheres of the Nigerian socio-economic system. All policy attempts to curb this vice have not been yielding expected results. To curb this menace, Muhammadu Buhari's administration put a whistle-blowing policy to expose corrupt practices in all sectors of the nation. This policy tends to have recorded incredible success, especially in recovering misappropriated funds in the country. However, in the education sector, there seems to be paucity in research done that exposed the corrupt practices inherent and proffer a strong argument for the adoption of whistle-blowing policy as a panacea for qualitative education. It is against the preceding that this study advocates the importance of whistle-blowing in the education sector in Nigeria and how it will help reduce and curb corruption in the educational system. The study begins with an Introduction, literature review, methodology, the central discourse, conclusion and recommendations. The study adopted an exploratory research method and relied on secondary data collection and analysis sources done thematically. The study found that whistle-blowing policy would be more effective in educational institutions if there is a proper communication channel for reporting wrongdoings. It also found out that the ranking of staff in the academic institution discourages whistle-blowers. This study recommended that there should be proper mechanisms of communication for whistle-blowers to report corruption cases in the education sector and encourage staff to report wrongdoings in the institution.
\end{abstract}

Keywords: Corruption, Education, Nigeria, Policy, Whistle-blowing

\section{INTRODUCTION}

In the current administration's fight against corruption, the whistle-blowing policy is not a new phenomenon. In the Nigerian public and private sectors, corruption has been identified as the primary cause of underdevelopment and challenges to the country's socio-economic growth. Corruption is an act that deviates from the official rules of conduct that govern the actions of someone in a position of public authority due to a private motive such as wealth, power, or status (Rotimi, 2013). As defined by those mentioned earlier, corruption is an aberration from a company's, organisations', or government agencies or parastatals' standard operating procedure, rules, or norms for personal or relative gain.

The concept of corruption has become ideologically, ethically, culturally, politically, and intellectually ambiguous to the point where people and society as a whole have lost sight of its deleterious and dependent influence. It comprises unethical transactions aimed at influencing the normal development of procedures and affecting perceptions and trustworthiness stances. The notion can be defined as an extreme fascination with obtaining income or benefits by illegal, corrupt, and often criminal means by persons whose primary 
goal is ego-boosting and self-exaggeration, with adverse effects for the rest of society (Shopeju, 2010).

However, despite the formation of various agencies such as the Economic and Financial Crimes Commission (EFCC), Independent Corrupt Practices and Other Related Offenses Commission (ICPC), Code of Conduct Bureau, and others to help reduce or eradicate corruption in the country, corruption continues to grow in the public sector; particularly among the political class, with numerous accusations and cases of money laundering, misappropriation of public funds, and contract scavenging. These factors prompted President Muhammadu Buhari's administration, through the Ministry of Finance under Mrs Kemi Adeosun, to implement a whistle-blowing policy that will allow Nigerian citizens to serve as regulators for corrupt acts. According to Mrs Kemi Adeosun, Minister of Finance, the policy's principal purpose is to aid in the fight against financial crimes and corruption by enhancing financial crime exposure and rewarding whistleblowers. Whistle-blowers are encouraged and granted protection from provocation or threats by their superiors or employers to encourage such disclosure.

Corruption has become so pervasive in Nigerian society that it has infiltrated every institution. It has become a common occurrence in the educational system, affecting higher education institutions worldwide. Education is essential more than ever in gaining access to lucrative employment, positions of authority, and other benefits. According to research carried out at institutions across the United States, up to $90 \%$ of students engage in academic corruption (Rabi et al., 2006). According to a review of numerous studies, academic corruption was pervasive on university campuses (Seals et al., 2014).

The public disclosure of such wrongdoings may aid in the reduction of corruption in the education sector and improve educational institutions' effectiveness. This paper will attempt to describe its basic concepts, which are whistle-blowing and education. It will examine the history of whistle-blowing policy in Nigeria, identifying how the whistle-blowing policy has helped curb corruption in Nigeria. Whistle-blowing policy as an imperative for quality education will also be analysed. It also aims to conclude the extent whistle-blowing has helped in the fight against corruption and proffer recommendations. This paper consists of Abstract, Introduction, and Conceptual Discourse: Theoretical Framework; Whistle-blowing Policy as an Imperative for Quality Education in Nigeria; Conclusion and Recommendations.

\section{LITERATURE REVIEW}

The concepts of whistle-blowing, education and the history of whistle-blowing policy in Nigeria are explained and examined in this section.

\subsection{The Concept of Whistle Blowing Policy}

Whistle-blowing is believed to have originated from two distinct but related activities. Firstly, it mimics the practice of police officers blowing whistles in an attempt to apprehend a suspect criminal. Secondly, it follows the custom of referees blowing the whistle to stop action during sporting events (Ogbu, 2017). From the preceding, it can be argued that whistle-blowing entails the exposure of illegal, immoral, or criminal actions to reduce, if not eliminating, wrongdoings.

Different scholars have interpreted the term "whistle-blowing" in different ways. One of these definitions is provided by Nader et al., as quoted in Rachagan and Kuppusamy (2012), as

'an act of a man or woman who, believing that the public interest outweighs the interests of the organisation he serves, blows the whistle on the organisation's involvement in corrupt, illegal, fraudulent, or harmful activity.'

According to Miceli et al. (2008), whistle-blowing is defined as the disclosure by a current or former member of an organisation of unlawful, immoral, or illegitimate acts under their employers' control to persons or organisations that may be able to take action. Whistle-blowing is proclaimed mainly by members of an organisation, according to this description. According to the Nigerian government, a whistle-blower is someone who freely discloses information in good faith about suspected misconduct or violation that has occurred, is occurring, or is about to happen (Tukur, 2016). Whistle-blowing is also described as the disclosure to the public by subordinates or employees of immoral or illegal behaviour in a public or private organisation that has the potential to harm a third party or the general public (Shaw, 2002). As a result, a whistle-blower is someone who expresses concerns about misconduct in an organisation. A whistle-blower is an organisational voice to get higher authority to correct policies, practices, and illegal behaviours. If properly implemented, the whistle-blowing policy can aid in the detection of fraud, as well as the implementation of actions to address wrongdoings or imbalances before they become widespread, potentially reducing the costs and losses experienced as a result of fraud (Chung, 2004). 
Internal and external whistle-blowing are the two types of whistle-blowing. Internal whistle-blowing involves reporting unethical behaviour to a supervisor within an organisation. In contrast, external whistle-blowing involves revealing unethical behaviour to outside individuals who are deemed to have the authority to change it. It is assumed that the motivation for internal whistle-blowing is contingent on effective internal complaint channels in the organisation. On the other hand, internal whistle-blowing should be used first before venturing outside an organisation's borders. Internal whistle-blowing, if executed properly, has the potential to conceal the organisation's negative state from the general public. Whistle-blowing can be done in public or in private. Whistle-blowing becomes public when the disclosure relates to a public company and private when it has to do with a private company or an individual.

According to Section 3 of the 2017 Bill, an act of disclosure may be made if it can be demonstrated that a public authority, a public officer, or a public sector contractor is, has been, or intends to be involved in illegal behaviour while performing a public duty. It's also possible that there's been a perversion of justice, an act or omission that violates a written law or an act or omission that puts the public's health in danger, jeopardises public safety, or causes environmental damage. The significance of these provisions is that whistle-blowing must come from a reliable source that primarily considers public interest.

\subsection{The Concept of Education}

Training, nurturing, and parenting are all terms used to describe education. Its purpose is to lead to a destination, which is referred to as an educational goal. Before one can say that education has properly achieved its function, it must first achieve a definite goal: a destination. According to Price-Mitchell (2014), education has become synonymous with completing a particular course or earning a specific school certificate or degree.

Formal education is provided by recognised public and private agencies that are institutionalised, intentional, and planned. It is made up of an initial education framework designed for the younger population to prepare them for entering the labour market. Education, on the other hand, is not limited to children and teenagers; it also encompasses a wide range of demographics, including vocational, special needs, and adult education, all of which are typically registered and approved as essential components of the formal education system by national education authorities (UOE, 2018). Non-formal education, on the other hand, does not follow the paradigm of formal education because it requires less time and effort. It generally does not require the individual's presence and has non-contiguous communication characteristics. Informal education encompasses a variety of educational methods used in society; it does not adhere to any organised or systematic vision of education, and it does not always require the objectives and modules found in the standard curriculum. It is aimed at students as well as the broader public (Dib, 1988).

Education is defined as a learning cycle in which a person acquires information and comprehends high-level explicit topics. The information obtained about an individual has an example of thought and behaviour based on their instruction. When it comes to education, the issue of what education is for is always raised. There are diverse perspectives on what it should be for, not simply relying on their values and beliefs about what education should achieve. To clarify, the recognition of educational systems serves a variety of purposes (Biesta, 2015). Qualification plays a significant role in education, particularly formal education. This is concerned with providing knowledge, skills, and understandings to children, adolescents, and adults, as well as the attitudes and forms of judgment that enable them to do "something," which can range from the very specific (as in vocational or professional education) to the much more general (such as the role of education in preparing children for life in highly complex societies). Socialisation is another function of education. It has to do with how people are initiated and made a member of existing social, cultural, political, professional, or religious organisations, customs, and traditions through education. In some circumstances, socialisation is intentionally encouraged, such as when the goal is to instil the value of democratic citizenship or specific professional communities' methods of doing and being (Biesta, 2015).

Individual students have access to distance learning all over the world beyond physical borders, from a oneroom rural classroom with one instructor instructing pupils in several grades to individual students tapping into distance learning all over the globe beyond physical borders (Lott, 2010). However, in the 21st century, education does not always imply earning credits toward a specific degree or credential. That is not to suggest that formal education has lost its relevance, but rather to recognize the need for continual informal education and shared information, particularly performance-based knowledge and teamwork (Lott, 2010).

Education plays a critical role in every nation's growth, and its significance cannot be overstated on a global scale. Furthermore, education has influenced every area of society's evolution, with its ramifications affecting every part of human life (Otonko, 2012). 


\subsection{The History of Whistle-blowing in Nigeria}

After the failure of international firms such as Eron, Tyco International, Adelphia, Peregrine Systems, and WorldCom, which resulted in the Global Economic Meltdown in 2001, this strategy was first implemented in the United States of America. The failure of these firms necessitates the development of the policy to prevent significant future losses to shareholders due to financial irresponsibility and a manager's window-dressing report at the expense of stakeholders. In response to several major corporate and accounting scandals in the United States, US Senator Paul Sarbanes and US Representative Michael G. Oxley sponsored and approved the Sarbane-Oxley Act 2002, which contains 11 provisions, in 2001. The Act protects insiders who report suspected financial irregularities in an organization from intimidation, dismissal, or unfair punishment by employers or managers of the victim organization. Whistle-blowing is not a new word in Nigerian politics; it has been used in corporate governance of financial and non-financial organisations before being adopted into President Muhammadu Buhari's anti-corruption campaign. In Nigeria, particularly in the banking sector, the whistle-blowing policy is in place. The Central Bank of Nigeria's 2012 Guideline Section 3.1 offers a basis for whistle-blowing for banks and other financial institutions in Nigeria, according to First Bank of Nigeria (2016) in an ethical report. Another form of whistle-blowing in the country's banking sector is Section 5.3.1 of the Code of Corporate Governance for Banks and Discount House.

According to Adeyemo (2015), efforts have been taken within the Nigerian banking industry to curb unethical practices and severe wrongdoings. Some statutory regulations, most notably the Guidelines released by the Central Bank of Nigeria (CBN) in 2012, reflect these attempts. These Guidelines look at how to effectively promote good corporate governance and direct banks and non-financial organisations to put measures in place to make the whistle-blowing system more accessible.

The Ministry of Finance, led by its Minister, Mrs Kemi Adeosun, established the Whistle-Blowing Portal on the Federal Ministry of Finance's website on October 1, 2016. This policy is the first of its kind in Nigeria's Federal Government's anti-corruption efforts. Despite erroneous reports that the previous administration of Goodluck Jonathan started the initiative, the recognition for it goes to President Muhammadu Buhari's administration. The Whistle-Blowing Policy has no legal backing yet, as the National Assembly has yet to enact the Whistle-Blowing Protection Bill.

\section{METHODOLOGY}

The study used an exploratory research method to focus on corruption, whistle-blowing policies in education, and other unethical behaviours throughout countries, with a specific focus on Nigeria. The research aims to examine the literature on whistle-blowing and education and the history of whistle-blowing. This study was a qualitative research project that used secondary data from reports, journal articles, books, media reports, and other policy documents.

\section{WHISTLE-BLOWING POLICY: AN IMPERATIVE FOR QUALITATIVE EDUCATION IN NIGERIA}

Since independence, the Nigerian government has acknowledged the unique education role as catalyst for individual and societal development. Over the years, education in Nigeria has appeared to decrease, whether in terms of infrastructure or the output of accessible graduates; lack of suitable infrastructure, high rates of school dropouts and out-of-school children, widespread failures in external secondary school examinations, brain drain of lecturers and now students, and other issues. Numerous studies have highlighted education as a crucial factor in determining a country's political, cultural, and economic dominance. Human capacity is improved and exploited for national development through these educational institutions, as no nation can progress without educational institutions (Egbefo, 2102).

Nigerians' ability to recognize the value of education and achieve the country's objective of becoming a leading economy mainly depends on how the country converts its youths into highly skilled and prepared workers who satisfy the global standard. The effectiveness or ineffectiveness of an educational system is determined by how well it benefits its beneficiaries (Summer, 2008). Throughout history, societies have relied on education for guidance. According to Chimombo (2005), education has always served to nurture the innovative skills of individuals in a society, which has resulted in opportunities for changes in a nation's economic, political, sociological, and moral outlook. Scholars point out that students and parents use incentives, inappropriate gifts, and school donations to influence decisions about their children and wards in a systematic and unethical manner (Nwaokugha \& Ezeugwu 2017).

Education serves several functions, one of which is to categorise people according to their abilities. As a 
result of corruption, individuals who are unqualified for positions and professions are placed in the role of education, which has repercussions for society. According to Nwaokugha \& Ezeugwu (2017), corruption in the educational sector depletes the educational system's quality and impacts the country's moral advancement and long-term development. Corruption in educational administration takes many forms, such as entrance examinations into institutions that are often based on the individual seeking admission rather than on merit.

In the recruitment and advancement of academic and non-academic staff, these positions are given to unqualified individuals, denying qualified people the chance to contribute to the body of knowledge. Senior staff members in educational institutions, who have access to funds, misuse these funds for their own selfish and personal gain.

Corruption in Nigerian institutions has harmed the country's social, economic, and educational systems. According to Suleiman (2005), corruption combined with economic and political incompetence has resulted in instability and blatant abuse of authority, resulting in deteriorating infrastructure, insufficient staffing, misappropriation of grants, trust funds, loans, and the disappearance of entire projects.

Whistle-blowing, as previously stated, is an act in which employees of an organisation report wrongdoings within the company. As previously indicated, the rate of corruption in an institution such as the education sector is significant, and it has infiltrated educational institutions. The whistle-blowing policy is a mechanism for exposing wrongdoing in organisations, and it is required to receive a quality education. Whistle-blowing is essential to educational institutions because it allows for the detection of fraud and misbehaviour. Whistleblowing in the education sector is critical to society because it helps uncover issues such as unethical conduct that affects science and research integrity, which is crucial to society's trust in research; flaws in the institution's legal and moral duty of care to students and staff; and financial misconduct, such as the misappropriation of funds (Do Better Academia, 2011).

Whistleblowing is done in the pursuit of creating a difference in the system by resolving the underlying issues and in the hope that their efforts would make things better organized and achieve the desired improvement in the institution's functioning and effectiveness (De George, 1990). Whistleblowing done with this goal protects the educational institution's interests and calls for a significant change in the status quo. Whistleblowing has been shown in studies to improve organizational effectiveness (Balci et al., 2012).

Although whistle-blowing is an effective method for reporting wrongdoings in the educational system, various barriers prevent whistle-blowers from disclosing these wrongdoings. Whistle-blowers in the education sector are discouraged from revealing because they are concerned about reprisal and not getting the desired results. In addition, junior staff in educational institutions are afraid of exposing senior colleagues to their wrongdoings. According to a few studies, one of the most common reasons for not engaging in whistleblowing is the fear of not getting results (Kaptein, 2011; Bjorkelo, 2103). Another factor is the accessibility of communication channels. If a good communication channel is present, employees are more inclined to blow the whistle internally (Gupta \&Chaudhary, 2017).

\section{CONCLUSION AND RECOMMENDATIONS}

This study examines the usefulness of whistle-blowing as a tool and mechanism for combating corruption and achieving high-quality education. Whistle-blowing, it was discovered, should be advocated to prevent violators from abusing others or engaging in misconduct. The work ethics of staff members encourage them to address their complaints to the proper authorities within the company before contacting other agencies. The paper drew attention to several challenges that plague the educational system. The whistle-blowing policy as an imperative for qualitative education in Nigeria sparked a discussion that concluded that the policy is appropriate for a good education in Nigeria.

A significant recommendation of this study is that efforts should be made to provide a formal channel of communication for reporting misconduct, as this will positively impact educational institution employee intentions. Other criteria include organisational support and management guarantee that appropriate action would be taken when reporting is completed. In addition, the Nigerian government should pass the WhistleBlower Protection Bill to ensure that whistle-blowers are protected from danger following their disclosure. 


\section{REFRENCE LIST}

Adeyemo, F. (2015). Whistle-Blowing: The Position of Nigerian Legislation in Banking. Journal of Law, Policy and Globalisation (41), 2224-3240.

Balci A., B. A. (2012). The Relationship Between Organisational Socialisation, Organisational Identification and Orgainsational Citizenship: A Survey on Primary School Administrators. Journal of Educational Sciences Research, Vol 2, No 2, 47-74.

Biesta, G. (2015). Educational Philosophy. Internationak Encyclopedia of the Social \& Behavioral Science (2), 255-260.

Bjorkelo, B. (2103). Workplace Bullying after Whistle-Blowing: Future Research and Implications. Journal of Managerial Psychology, Vol28 No.3, 306-323.

Chimombo, J. (2005). Issues in Basic Education in Developing Countries: An Expoloration of Policy Options for Improved Delivery. Journal of International Cooperation in Education, 129-152.

Chung, J. M. (2004). An Examination of Factors Affecting External and Internal Whistle Blowing by Auditors. Sydney.

De George, R. (1990). Business Ethics 3rd Ed. New York: Macmillan Publishing.

Dib, C. (1988). Formal, Non Formal and Informal Education: Concepts/Applicability . "Cooperative Networks in Physical Education- Conference Proceedings 173 (pp. 300-315). New York: American Institute of Physics.

Do Better Academia. (2011). Whistle-blowing in Universities. Retrieved from http://www.dobetteracademia.co.uk

Egbefo, D. \&. (2102). Corruption in the Nigerian Educational System: It's Implication in Manpower and National Development in the Age of Globalisation.

First Bank of Nigeria. (2016). Whistle-Blowing Policy and Procedures. Lagos: First Bank of Nigeria Holdings Publication.

Gupta, K.P and Chaudhary, N.S. (2017). Prioritising the Factors Influencing Whistle-Blowing Intentions of Teachers in Higher Education Institutes in India. Procedia Computer Science Vol.122, 25-32.

J.T. Lott, C. B. (2010). Beyond Racial, Ethnic and Gender Bias in Education Statistics. International Encyclopedia of Education (3), 581-588.

Kaptein, M. (2011). From Inaction to External Whistleblowing: The influence of the Ethical Culture of Organisations on Employee Responses to Observe Wrongdoing. Journal of Business Ethics Vol.98, No.3, 513-530.

Kuppusamy, S. R. (2012). Encouraging Whistleblowing to Improve Corporate Governance: A Malaysian Initiative. Journal of Business Ethics 115(2).

Marcia P. Miceli, J. N. (2008). WhistleBlowing in Organizations. Routledge.

Nwaokugha, D. \&. (2017). Corruption in the Education Industry in Nigeria, Implications for National Development. European Journal Of Training and Devlopment Studies 4 (1), 1-17.

Ogbu, S. U. (2017). Whistleblowing Policy as a Mechanism for Energizing The War Against Corruption in Nigeria. International Journal of International Relation, Media and Mass Communication Studies , 16-32.

O'Malley, B. (2010). Global: Detecting Application Fraud. University World News.

Otonko, J. (2012). University Education in Nigeria: History, Successes, Failures and the Way Forward. International Journal of Technology and Inclusive Education (IJTIE) 1(2), 44-48.

Price-Mitchell, M. (2014, May 12). What is Education? Insights from the World's Greatest Minds. Retrieved from https://www.psychologytoday.com/int//blog/the-moment-youth/201405/what-is-educationinsights-the-worlds-greatest-minds

Rabi, S. P. (2006). Characteristics, Prevalence, Attitudes and Perceptions of Academic Dishonesty among Pharmacy Students. American Journal of Pharmaceutical Education 70(4), 1-8. 
Rotimi, E. (2013). Analysis of Corruption and Economic Growth In Nigeria. Afro-Asian Journal of Science.

Seals, M. H. (2014). Teaching Assistants' Preparation for Attitudes Towards and Experiences with Academic Dishonesty: Lessons Learned. International Journal of Teaching and Learning in Higher Education 26(1), 26-36.

Shaw, C. (2002). Fighting Fraud. CMA Magazine, 53-54.

Shopeju, C. (2010). Elite Corruption and the Culture of Primitive Accumulation in 21st Century Nigeria. International Journal of Peace and Development Studies, 15-24.

Sulieman, B. (2005). Corruption and Development. London: Frank Cass.

Summerr, D. (2008). A Measurment of Student Satisfaction Level as a Means of Program Evalaution. Baker University.

Tukur, S. (2016, December 21). How Nigerians can make money, be protected in new Whostle Blowing Policy. Retrieved from http://www.premiumtimesng.com/news/headlines/218643-nigerians-canmake-money-protected-new-whistle-blowing-policy-finanace-minister.hmtl

UOE. (2018). UOE Data Collection on Formal Education: Manual on Concepts, Definitons and Classification. Montreal, Paris and Luxemborg: UNESCO-UIS/OECD/EUROSTAT. 